\title{
IMPROVING THE EFFICIENCY OF CARIES PREVENTION DUE TO THE TIMING OF THE ERUPTION AND MINERALIZATION OF PERMANENT TEETH IN CHILDREN ENVIRONMENTAL PROBLEMS OF THE REGIONS OF THE REPUBLIC OF UZBEKISTAN
}

\author{
M. SH. Afakova ${ }^{1}$ \\ S. S. Murtazaev ${ }^{2}$ \\ ${ }^{1}$ Bukhara state medical Institute \\ ${ }^{2}$ Tashkent state dental Institute
}

\begin{abstract}
The process of mineralization or maturation of enamel occurs within 3-5 years after teething. Numerous clinical observations indicate that caries develops most intensively in the first years after teething, which coincides with the period of immature enamel. Due to the mineralization of enamel, its resistance to caries increases. The terms of eruption and mineralization of permanent teeth in school-age children with the physiological development of the child coincide with the terms of complete resorption of the roots of temporary teeth.
\end{abstract} problems.

Key words: caries prevention, eruption time, mineralization of permanent teeth, in children, environmental

\section{Introduction}

There is a certain pattern of physiological teething: certain terms, pairs, and order of teething. Any change in these three patterns leads to a violation of the formation of the dentoalveolar system. The causes of the disorder can be General and local factors: heredity, climatic conditions, nutrition, etc. All this leads to a violation of the terms of eruption and mineralization of permanent teeth and disrupts the mechanism of formation of ESR.

Eruption and mineralization of permanent teeth is an important aspect of a child's growth and development. Teething is a very complex and not fully understood process. One of the most important stages in the formation of the child's dental system is the period of replacement bite. Monitoring the eruption of permanent teeth and the formation of occlusion is an important point that requires special attention from a pediatric dentist. It is important to emphasize that the study of the features of eruption and mineralization of permanent teeth is of diagnostic and prognostic interest and also justifies the feasibility of dental prevention of school-age children (V. G. Galonsky, A. A. Radkevich, N. V. Tarasova, A. I. Volynkina).

To date, in our Republic there are no comprehensive studies on the timing of eruption and reflecting the dynamics of mineralization of the enamel of permanent teeth in children. There is a work By F. L. Mirsalikhova devoted to the study of the degree of mineralization with the timing of eruption of the first permanent molars in children of the city of Tashkent. Based on the above, the study of the timing of eruption and mineralization of permanent teeth in children is very relevant, has great practical and theoretical significance, since the results obtained will be taken into account when organizing dental care for the children's population of our Republic.

\section{Materials and Methods}

To Study the timing of eruption and mineralization of permanent teeth in school-age children.

The who regional office for Europe has developed the policy document "Health 21-health for all in the twenty-first century". It presents the European goals for children's dental health to be achieved by 2020, including: over $80 \%$ of 6 -yearolds must have intact teeth, while the average value of the CPI index for temporary teeth should not exceed 2.0.

Numerous literature data indicate that the timing of teething in children living in different countries is very similar. The first permanent molars erupt at the age of 6-7 years. These teeth are exposed to an active carious attack as a result of increased risk factors: incomplete mineralization process and the stressful effect of the period of adaptation of children to school on the child's body, which reduces its non-specific resistance. Thus, by the end of the first grade, most children have not only distinct deviations in neuropsychiatric health (up to 54\%), but also diseases of the digestive system (29.4\%), a decrease in hemoglobin in the blood, an increase in asthenia, the appearance of functional disorders of the cardiovascular system, complaints of headaches in the afternoon, fatigue, irritability, tearfulness, sleep and appetite disorders, night terrors [1.3.7].

3. Main part

The development and course of caries is largely determined by the ratio of the processes of de-and remineralization of the surface layer of enamel. The targeted use of the remineralization effect to increase the resistance of dental tissues is one of the most promising ways to prevent caries during teething. The direction of remineralizing therapy and prevention of dental caries is well-founded and is based on clear scientific facts, provisions and evidence [2.5.8.10]. Most often in our country, mass and collective methods of prevention are used, which, on average, reduce the growth of caries by up to $50 \%$. Carrying out stereotypical prevention, even taking into account regional characteristics, does not allow us to hope for a high end result.

Dental caries in children is not the same. Features of the clinical course of dental caries in children are related to the nature of the structure of the hard tissues of the teeth and the reactivity of the body [4.6.9]. It is believed that when determining the therapeutic and preventive tactics of a doctor, the leading component is always the degree of activity of 
caries. Current trends provide for a differentiated approach to primary prevention and treatment of dental caries, while the content, scope of treatment and prevention measures, the frequency of repeated visits during medical examinations and rehabilitation should be determined by the degree of activity of the carious process [12.15.18]. Modern dental schools have developed principles of therapeutic and preventive measures to strengthen the resistance of organs and tissues of the oral cavity, improve self-cleaning and hygiene, reduce the intensity of pathogenic factors, but the details of these measures depending on the degree of activity of the carious process during the eruption and mineralization of the first permanent molars have not been developed, which leads to stereotypical prevention without taking into account the characteristics of identification groups and a decrease in the quality of medical and preventive work. In this connection, this study was undertaken, its purpose and objectives were determined [13.14.16.17].

Numerous literature data indicate that the timing of teething in children living in different countries is very similar. The first permanent molars erupt at the age of 6-7 years. These teeth are exposed to an active carious attack as a result of increased risk factors: incomplete mineralization process and the stressful effect of the period of adaptation of children to school on the child's body, which reduces its nonspecific resistance [19.20.22.23]. Thus, by the end of the first grade, most children have not only distinct deviations in neuropsychiatric health (up to 54\%), but also diseases of the digestive system (29.4\%), a decrease in hemoglobin in the blood, an increase in asthenia, the appearance of functional disorders of the cardiovascular system, complaints of headaches in the afternoon, fatigue, irritability, tearfulness, sleep and appetite disorders, night terrors [21.24.28]. Incomplete mineralization of the hard tissues of permanent teeth at this age is a factor of increased risk of caries. The development and course of caries is largely determined by the ratio of the processes of deand remineralization of the surface layer of enamel. Directed use of the remineralization effect to increase the resistance of dental tissues is one of the most promising ways to prevent caries during teething [25.26.27]. The direction of remineralizing therapy and prevention of dental caries is well-founded and is based on clear scientific facts, provisions and evidence.

Current trends provide for a differentiated approach to primary prevention and treatment of dental caries, while the content, scope of treatment and prevention measures, the frequency of repeated visits during medical examinations and rehabilitation should largely be determined by the degree of activity of the carious process [29.30.31.32]. Modern scientific dental schools the principles of treatment and preventive measures to strengthen the resistance of organs and tissues of the mouth, improvement of self-purification and hygiene, reduce the intensity of the pathogenic factors, but the detail of these activities depending on the degree of activity of caries during the eruption and mineralization of the first permanent molars has not been developed, leading to the stereotypical conduct of prevention without considering the peculiarities of identity groups and reduces the quality of preventive and curative work [33.39.40.41].

The prevalence of caries among children remains an urgent issue in our time. The incidence of caries, especially in young children, remains high. According to who, at the age of one year, some children in $15 \%$ of cases are found affected by caries teeth, by three years the prevalence of caries in children reaches $46 \%$, by six years- $96 \%$. In this regard, improving the system of dental care for children in the country and maintaining it at the current level is an extremely important problem facing the organizers of practical health care. [34.35]. Based on clinical studies, it has been established that the health of baby teeth and their caries resistance largely depends on the conditions of the child's antenatal development. This is due to the fact that the laying of temporary teeth occurs at 7-8 weeks of pregnancy, the development of rudiments lasts up to 20 weeks. [37.38.39].

Especially intense mineralization of teeth occurs in the last months of pregnancy. The high incidence of oral tissue in children with visceral pathology of the expectant mother, as well as in children born to mothers with severe pregnancy, is well known. The most pronounced "risk periods" for the development of dental pathology are the period of pregnancy, the first year of the child's life, and the period of teething. Already in the early stages of pregnancy is the deterioration of the hard tissues of the teeth as against the General state of health of the mother and due to poor hygienic condition of the oral cavity and changes in the composition of oral fluid. This makes it necessary to carry out preventive measures throughout the entire period of pregnancy [34.35]. Pregnancy toxicosis is one of the important adverse factors affecting the incidence of caries in temporary teeth. Children born to mothers with late pregnancy toxicosis and under the supervision of a dentist for 3 years had a higher prevalence and intensity of caries compared to children whose mothers had a physiological pregnancy [26, 28, 33, 40].

Not the last place in the occurrence of dental caries is given to the nature of feeding an infant. In children who are on artificial feeding, tooth decay begins earlier and is more intense. Timely introduction of complementary foods (cottage cheese, juices, vegetable and fruit puree) is important, since these products are the main source of trace elements necessary for the formation of dental caries resistance [25, 27, 35]. The leading role in the study of the level of oral health is the quantitative characteristics of dental damage by the carious process, determined using various indices. One of the main indexes is the intensity of tooth decay. For this purpose, for the replacement bite, the determination of quantitative values of $\mathrm{CP}+\mathrm{CP}$ is applied, where $\mathrm{K}$ and $(\mathrm{K})$-the number of permanent and milk carious teeth, $\mathrm{N}$ and (n)-the number of permanent and milk filled teeth, $\mathrm{Y}$ - the number of removed permanent teeth [34.37].

\section{Conclusion}

For temporary teeth, the CP indicator is calculated - the number of carious and filled teeth of temporary bite, 
although this does not reflect the actual picture of the intensity of caries, since removed baby teeth due to complicated caries are not taken into account. Therefore, the determination of the prevalence and intensity of caries in children of early and preschool age, taking into account the removed baby teeth due to complicated caries (CPI+CPI index), is timely and appropriate in order to strengthen the prevention of caries of baby teeth and increase the level of dental care for children of early and preschool age. Analyzing the above, we can conclude that an urgent problem today is a more in-depth study of the intensity and prevalence of caries in children of early and preschool age, taking into account risk factors and changes in homeostasis, which will allow us to assess the age structure of dental diseases in children and determine the scope of preventive measures [40.41].

\section{References}

1. Avraamova O. G. Sanitary and hygienic education and training of the population in programs of prevention of dental diseases/ O. G. Avraamova // Dentistry. -1998 Special issue-P. 41

2. Avraamova O. G. Prospects of development of preventive dental programs in Russia (historical and situational analysis) / O. G. Avraamova, V. K. Leontiev // Stomatology 1998. - no. 2-P. 11-18.

3. Admakin O. I. Dental morbidity of the population in various climatic and geographical zones of Russia. . Cand. med. Sciences/ O. I. Admakin.-M.: the Museum, 1999.

4. Alimsky A.V. Principal approaches to the organization of prevention of dental diseases in a market economy / A.V. Alimsky // New in dentistry 1997 - No. 5. -P. 79.

5. Belova N. A. dental Caries of deciduous teeth in premature infants/ N. And. Belov, Proc. Perm. state med.in-t Perm, 1993 p. 5.

6. Belyaev V. V. the Prevalence of major dental diseases and their prevention in the pediatric population of the Tver region: abstract. dis. . candidate of medical Sciences/ V. V. Belyaev. Tver, 1998. - 18 p.

7. Benevolenskaya L. I. Epidemiology of rheumatic diseases / L. I. Benevolenskaya, M. M. Brzezovsky. - M.: Medicine, 1988.

8. Benyamin Perets. "Baby bottle tooth decay" a danger to the teeth of infants and young children / P. Benjamin,the Eliezer Edelman // International medical journal-1999. - no. 1-2. - Pp. 104-107.

9. Bobrik V. V. Prevention of errors and complications in physical methods of diagnosis and treatment of dental diseases /V. V. Bobrik, M. P. Bushueva,G. E. Chernihiv // Prevention and treatment of dental diseases in children. Tver, 1995, Pp. 59-63.

10. Borisenko A.V. Caries of teeth/A.V. Borisenko, M. P. Bushueva, G. E. Chernihiv. -Kyiv,2000.- S. 12-36.

11. Borovsky E. V. Composition and properties of saliva in normal and caries: a method recommendations/ E. V. Borovskiy, P. A. Leus, E. M. Kuzmin.-M.: MMSI them. N. N. Semashko-1990 36C.

12. Borovsky E. V. diseases of the mucous membranes of the mouth and the lip / E. V. Borovsky, A. L. Mashkilleyson. M.: Medicine, 1994 - 134c.

13. Borovsky E. V. Caries of teeth/ E. V. Borovsky, P. A. Leus M.: Medicine, 1990. -256 p.

14. Burdina O. V. Prevention and treatment of dental caries in people with increased consumption of refined carbohydrates, author of the thesis of the candidate of medical Sciences / O. V. Burdina. 1990.

15. Vasina S. A. Clinical and laboratory justification of the use of some means and methods of prevention of dental caries and gingivitis in schoolchildren: dis. . candidate of medical Sciences / S. A. Vasina-M., 1994.

16. Vinogradova T. F. medical Examination of children at the dentist/T. F. Vinogradova. - M.: Medicine, 1990. $183 \mathrm{~s}$.

17. Distel V. A. Lifetime solubility of the surface layer of enamel of human teeth and the influence of various factors on it: dis. . Cand. med. Sciences / V. A. Distel. Omsk, 1975. - 130 p.

18. Drozhzhina V. A. Prevention of dental caries in children based on local use of drugs containing natural biologically active substances / V. A. Drozhzhina, S. A. Tumanova, P. M. Chernobyl // New in dentistry. 1996. No. 4. - Pp. 16-24.

19. Drozhzhina, V. A. three-year experience in the application of fissure in practical health care / V. A. Drozhzhina, N. E. Abramova // 5th Congress of Stomatologic Association of Russia : collection of scientific works. Tr. M., 1999. - S. 46-47.

20. Durdynets M. K. Socio-hygienic aspects of dental morbidity in nagaragawa women / M. K. Durdynets, A. V. Alimskii // Dentistry. 1993. - No. 1. - Pp. 60-65.

21. Elizarova V. M. Ionized calcium in saliva in multiple caries / V. M. Elizarova, Yu. a. Petrovich // Dentistry. 1997. - Vol. 76, No. 4. - P. 6-8.

22. Zhelezny P. A. Primary prevention of dental diseases: textbook-method. manual / p. A. Zhelezny, V. V. Reva. Novosibirsk, 1996. 168 p.

23. Zhelezny P. A. Diagnostics of dental anomalies and deformities: method, recommendations / p. A. Zhelezny, N. A. Plotnikova. Novosibirsk, 1995. -166 p. 
24. Zhorova T. N. the process of maturation of permanent tooth enamel after eruption and the influence of various factors on it : autoref. dis. . candidate of medical Sciences / T. N. Zhorova. - Omsk, 1989. - 24 p.

25. Zyryanov B. N. dental Caries in the indigenous and foreign population of the Far North of the Tyumen region, mechanisms of development and prevention: author's abstract. . doctor of medical Sciences / B. N. Zyryanov. Omsk, 1998. - 47 p.

26. Zyryanov B. N. Clinical evaluation of new approaches to primary prevention of dental caries in children / B. N. Zyryanov, I. A. Lvova // Institute of dentistry. 2007. - No. 4. - P. 82.

27. Zyryanov B. N. Fundamentals of primary prevention in dentistry / B. N. Zyryanov. Omsk: OGMA Publishing house, 2001. - $96 \mathrm{p}$.

28. Ivanova G. G. Medico-technological solution of problems of diagnostics, forecasting and increase of resistance of hard tissues of teeth: author's abstract. . doctor of medical Sciences / G. G. Ivanova; Omsk state medical Academy. Acad. - Omsk, 1997. -48 p.

29. Ivanova G. G. Microlocalization of caries on the chewing surfaces of molars / G. G. Ivanova, R. G. Buyankina, T. N. Zhorova // Dentistry. - 1987. - No. 3. - P. 25-28.

30. The results of four years mass prophylaxis of dental caries in rural children fluoride compositions / V. G. Suntsov et al. / / Regional problems of health of the population : collection of scientific works. Tr. - Novokuznetsk, 1991.-S. 91-93.

31. Kakorina E. L. Socio-hygienic characteristics of dental morbidity in children / L. E. Kakorina // Healthy child : SB. nauch. Tr. -M., 1999. P. 191.

32. Kalinina E. N. General dental morbidity in children living in regions with different levels of environmental pollution / E. N. Kalinina, N. A. Lazareva, T. V. Elizarova // Environmental diseases: TEZ. Dokl. Chita, 1997. P. 14-15.

33. Cameron A. Handbook of pediatric dentistry / A. Cameron, R. Widmer. M.: Medpress-inform, 2003. - 284 p.

34. Vitamins and minerals for children's health: textbook of the Union of pediatricians of Russia, public Foundation "Healthy child", Scientific center for children's health, RAMS. M., 2005.

35. The impact of the learning conditions of children brushing different toothpastes on the state of hygiene of oral cavity / V. K. Leontev, etc.// Dentistry for all-2001 .-№4 (17)-P. 34-39.

36. Age dynamics of indicators of dental caries in preschool children/ I. V. Kuznetsova et al. / / Collection of scientific-practical works of the employees of the Central polyclinic №1 MEAs.-M., 1992.-P. 73-74.

37. Volkov, E. A. a study of the methods of treatment of early forms of dental caries : dis. . kand. med. nauk / E. A. Volkov. - M., MMSI, 1993.

38. Voronina E. P. Dental status of children born and living in the area of the aluminum plant location: autoref. dis. . candidate of medical Sciences / E. p. Voronina.- Volgograd, 1995. - 21s.

39. Galiulina M. V. Homeostasis in the system enamel of teeth-saliva / M. V. Galiulina, V. K. Leontiev // Dentistry1990. - No. 2. - P. 4-5.

40. Garber O. G. Violation of the process of self-cleaning of the mouth under the influence of a number of factors / O. G. Garber, V. B. Nedoseko, A. N. Pitaeva / / II Congress of dentists of Turkmenistan. Ashgabat, 1991.

41. Gnetova I. V. Dental morbidity and justification of comprehensive prevention in children.- Novosibirsk: Avtoref. dis. kand. med. nauk/ I. V. Gnetova. - M., 1999. p. 122

42. Fuzailova, G. (2020). EASTERN THINKERS ON THE PEDAGOGICAL MASTERY. The Light of Islam, 2020(2), 138-144.

43. Мадраимов, А., \& Фузаилова, Г. (2008). Манбашунослик. Тошкент: Ўзбекистон файласуфлар миллий жамияти нашриёти, 52.

44. Fuzailova, G. S. (2020). САМОИДЕНТИФИКАЦИИ КАК ЛИЧНОСТНОЕ РАЗВИТИЕ БУДУЩИХ УЧИТЕЛЕЙ. Педагогика ва психологияда инновачиялар, 9(3). 